\title{
Siva ekonomija v javnem prostoru: zapletene politične in prostorske ureditve na indonezijski ulični tržnici
}

\begin{abstract}
Zaradi močnega vala urbanizacije in omejenih možnosti formalne zaposlitve $\mathrm{v}$ velikih azijskih mestih se čedalje bolj krepi ulična prodaja, ki je zaradi neodobrene uporabe javnega prostora pogosto sporna in nezakonita. Nedeljska tržnica v Kuteku v indonezijski občini Depok se je morala z lokacije zraven univerze, na kateri je bilo običajno polno ljudi, preseliti v razmeroma odmaknjeno stanovanjsko sosesko, kjer pa prodajalci še vedno precej dobro poslujejo. Študija primera, predstavljena v tem članku, temelji na obsežnih terenskih opazovanjih in intervjujih ter pojasnjuje, kako je bila izbrana nova lokacija tržnice in kako je prostorsko urejena, da lahko zadovoljuje potrebe prodajalcev, stanovalcev in kupcev. V članku je predstavljeno,
\end{abstract}

kako so stanovalci in prodajalci razvili inovativen, odprt in samoorganiziran sistem upravljanja tržnice, ki se prilagaja spreminjajočemu se številu in lastnostim prodajalcev in kupcev. Čeprav sistem velja za učinkovito orodje, ki omogoča uspevanje sive ekonomije, zaradi omejenih načrtovalskih zmožnosti zahteva sodelovanje z drugimi deležniki, na podlagi česar se lahko rešujejo nepričakovani izzivi. Sodelovanje med deležniki je povečalo koristi in zmanjšalo slabosti sive ekonomije $\mathrm{v}$ javnem prostoru.

Ključne besede: ulična tržnica, ulični prodajalci, siva ekonomija, javni prostor, Indonezija 


\section{Uvod}

\section{1 Širjenje ulične prodaje v svetu, ki se čedalje bolj urbanizira}

Neskladen regionalni razvoj in slabo upravljanje v številnih državah v razvoju povzročata obsežno nenadzorovano urbanizacijo (Hossain, 2004). Zaradi hitre rasti mestnega prebivalstva mnogi prebivalci težko najdejo formalno zaposlitev (Ligthelm in van Wyk, 2004), ena izmed posledic rasti mest pa je tudi širjenje dejavnosti uličnih prodajalcev (Chirisa, 2009). Njihovo število močno narašča, pri čemer zasedajo javni prostor po večjih mestih držav v razvoju in poskušajo zaslužiti dovolj za preživetje (Faruque in Haque, 2010; Dunn, 2014). Po finančni krizi leta 1998 se je v številnih azijskih državah število uličnih prodajalcev občutno povečalo, saj je mnogo ljudi, ki so bili prej zaposleni v formalnem sektorju, izgubilo službo (Indira, 2015). Prodaja blaga na ulici je postala pomemben vir zaposlitve, storitev in prihodkov za revna mestna gospodinjstva (Fidler in Webster, 1996; Iyenda, 2005; Suriansyah, 2005; Estrada in Hondagneu-Sotelo, 2011). Izraz »ulični prodajalec « se nanaša na prodajalce na urejenih tržnicah, prodajalce, ki postavijo stojnice na pasovih ob robu cestišča, potujoče ulične prodajalce in prodajalce na domu (Cohen idr., 2002). Njihovo poslovanje je pogosto nezakonito, čeprav prodajajo zakonito blago in storitve (ILO, 2002). Njihova dejavnost zato ne poteka $\mathrm{v}$ ločenih gospodarskih krogih, ampak se prepleta $s$ formalnim sektorjem (Chen, 2007; Hossain, 2014).

Prisotnost uličnih prodajalcev na javnih prostorih ima pozitivne vplive tako v državah v razvoju kot v razvitih državah; ulični prodajalci so na primer postali nepogrešljiv del mestne krajine Los Angelesa, New Yorka in Čikaga (Munoz, 2012). V New Yorku (Roy, 2005) in Mumbaju (Anjaria, 2006) povečujejo javno varnost in izboljšujejo kakovost življenja v soseskah, kjer delujejo, čeprav jih mestne oblasti še vedno obravnavajo kot javno nadlogo. Veljajo za sestavni del nekaterih sosesk (Deguchi, 2005), stanovalcem pogosto zagotavljajo glavni dostop do hrane (Kabeer, 2004), hkrati pa poživijo javne kraje (Deguchi idr., 2005). Preobrazba javnih prostorov na podlagi ulične sive ekonomije je novost, ki učinkovito zadovoljuje potrebe mestnih prebivalcevin ljudi spodbuja k druženju (Jimu, 2005; Rojas, 2008), čeprav prisotnost uličnih prodajalcev običajno krši občinske predpise (Danesh, 1999). Kljub raznim pozitivnim vplivom je ulična prodaja v mestni politiki držav v razvoju še vedno zapostavljena (Jimu, 2005). Z vidika sodobnega načrtovanja navedena gospodarska dejavnost spodkopava javni red in državni nadzor (Cross, 2000), zato se v državah Latinske Amerike, kot je Kolumbija (Donovan, 2008), in azijskih državah, kot je Indonezija (Harjoko in Adianto, 2012), močno omejuje.
Želja po oblikovanju privlačnih globalnih mest (Robins in Askoy, 1996) je očarala številne vlade držav v razvoju, ki pri urbanističnem načrtovanju in določanju predpisov zato ne upoštevajo vidikov sive ekonomije, kot je ulična prodaja (Parthasarathy, 2003). Posledično njihovi razvojni načrti niso prilagojeni potrebam neformalnih mestnih dejavnosti (Perera in Amin, 1996) in še poslabšujejo prostorske težave v mestih v razvoju (Yankson, 2000). Lokalnim občinam pogosto primanjkuje politične volje, administrativnega znanja ali inovativnih upravljavskih strategij, potrebnih za učinkovito vključitev ulične prodaje v mestni gospodarski sistem (Morrell idr., 2011). Če vključitev uličnih prodajalcev ni premišljeno načrtovana, lahko to povzroči prezasedenost javnih prostorov in precejšnje okoljske težave, kot so prenatrpani pločniki in oviran prehod pešcev (Loukaitou-Sideris in Ehrenfeucht, 2011) ter slabe sanitarno-higienske razmere (Rakodi, 2005) zaradi smeti na ulicah, pločnikih in v odprtih odtokih, ki jih mestne oblasti niso več zmožne počistiti (Satterthwaite, 2003; Yankson, 2007). Mnoge empirične raziskave, opravljene v azijskih glavnih mestih, so sivo ekonomijo, vključno z ulično prodajo, preprosto obravnavale kot nekaj, kar je treba upravljati (Ong, 2006; Jiang idr., 2010), ob tem ko se mesto pospešeno razvija $\mathrm{v}$ globalno središče (Yeo idr., 2012). Upravljanje uličnih prodajalcev vključuje na primer določitev posebnega območja, kjer lahko opravljajo svojo dejavnost (Chai idr., 2011), ali uvedbo sistema za pridobitev dovoljenj za prodajo (Lincoln, 2008; Chiu, 2013). Tako država prizna obstoj ulične prodaje kot nečesa, kar ustvarja sistem za preživetje revnih mestnih prebivalcev in s tem zagotavlja red $\mathrm{v}$ družbi. Navedeni sistem ima izjemno nenavadno dinamiko samoregulacije, v katerem ni formalnega nadzora nad načrtovanjem (Dovey, 2012), zato je treba dobro razumeti, kako ulični prodajalci na mestnih območjih soustvarjajo prostor za potrebe sive ekonomije.

\subsection{Prikriti družbeni sistem, na katerem temelji prostorska ureditev uličnih tržnic}

Ulična prodaja poteka na javnih prostorih (Satterthwaite, 2003), natančneje na pločnikih (Jimu, 2005), ob poteh (Suharto, 2004), tržnicah (Brown, 2006), na avtobusnih postajališčih (Cohen idr., 2002) in drugih javnih krajih (Yankson, 2000). Oblike zasedanja uličnega prostora so ravno tako raznovrstne kot lokacije, odvisno od vrste območij in dejavnosti v bližini (Suharto, 2004), kot so območja za pešce (Dewar in Watson, 1990) ali prometna vozlišča in vozlišča za dnevne migrante (Bhowmik, 2005). Kot navaja Yankson (2000), je pri izbiri lokacije prodaje glavni dejavnik ta, da je območje privlačno za kupce, sledita razpoložljivost dovoznih cest in pomanjkanje drugih primernih lokacij. Izgon uličnih prodajalcev z nekaterih javnih prostorov lahko učinkovito onemogoči njihovo dejavnost (Idayanti, 2007), saj lokacija vpliva na viši- 


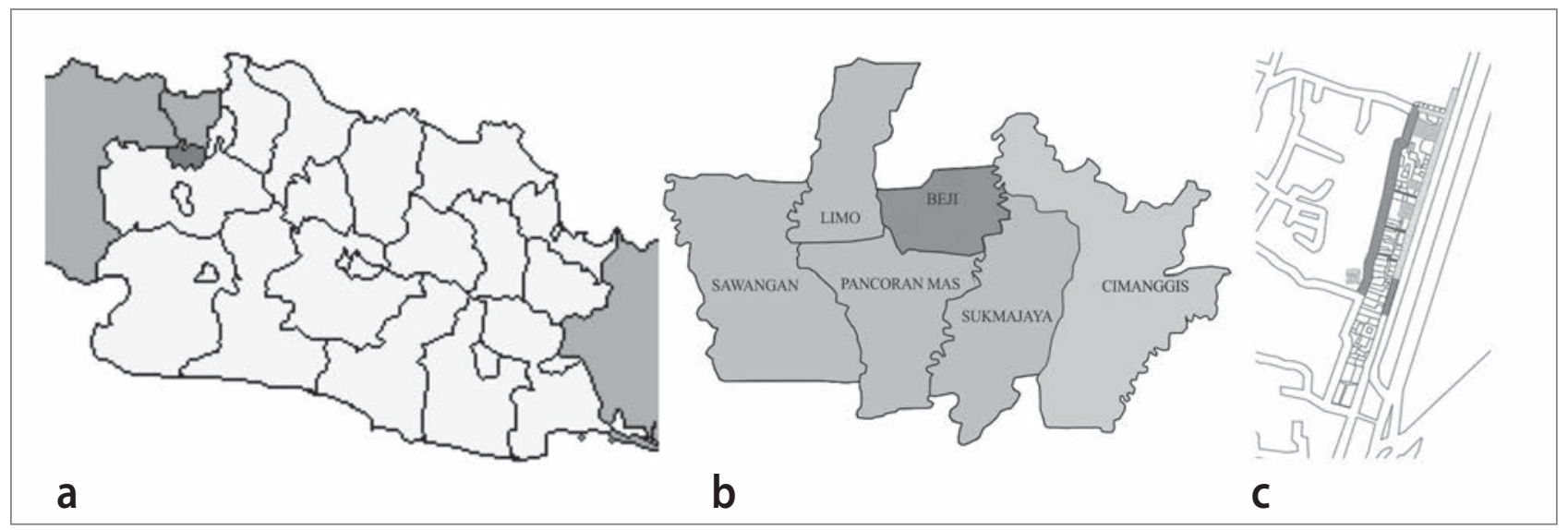

Slika 1: Lokacija občine Depok (a), okrožje Beji (b) in raziskovalno območje (c) (vir: Internet 1)

no najemnine stojnic in zmožnost ustvarjanja prihodka $(\mathrm{Su}-$ silo, 2011). Poleg tega so raziskave v Indoneziji pokazale, da sta narava posameznih krajev in njihova privlačnost za potencialne kupce (v glavnem zaradi dejavnosti v okolici) ključna dejavnika pri izbiri lokacije ulične prodaje (Suparwoko in Sriyana, 2006; Suparwoko, 2008). Brez dobrega razumevanja lokacijskih preferenc uličnih prodajalcev njihova načrtna premestitev na drugo območje zato ne more doseči želenih ciljev.

Raziskava petih tradicionalnih tržnic $\mathrm{v}$ Džakarti (Adianto, 2009) in študija tradicionalne tržnice v Bekasiju v Zahodni Javi (Libratono, 2012) sta pokazali, da se lokacija, vrsta prodajnih izdelkov in delovni čas uličnih prodajalcev ujemajo z vzorcem dejavnosti kupcev in proizvajalcev. $V$ vseh tovrstnih raziskavah je bilo ugotovljeno, da ima družbeni sistem, ki določa pravila za upravljanje in uporabo razpoložljivih virov, ključno vlogo pri prostorski ureditvi ulične prodaje na javnih mestih. Navedeni sistem vzpostavlja samoorganizacijo (Koolhaas, 2005; Mörtenböck in Mooshammer, 2007) pri kateri se oblikujejo prostorske ureditve na podlagi prilastitve ali ponovne prilastitve javnih prostorov (Isin, 1999; Boeri, 2003), ki temelji na posvetovalnem načrtovanju (Koolhaas in Cleijne, 2007) in kreativnih izračunih (Franke, 2006). Zaradi slabega dostopa do formalnih institucij morajo ulični prodajalci razviti nove ali pa izkoristiti obstoječe ureditve in nenapisana pravila za svojo samoorganizacijo, upravljanje in gospodarsko dejavnost (Lindell, 2008). Peters (2013) v raziskavi, opravljeni v indonezijskem mestu Surabaya, opisuje izjemno moč neformalnih dejavnosti in njihov prispevek $\mathrm{k}$ sodobnemu mestnemu razvoju na podlagi kolektivnega duha prikrajšnih skupin in delavskega razreda. Podobno opisuje tudi ObengOdoom (2011) v raziskavi o prožnosti in sposobnosti za preživetje neformalnih sektorjev v Gani, ki jim stalno grozi deložacija. Kljub stigmatizaciji neformalnost ustvari občutljiv sistem upravljanja, ki deluje v okviru formalnega upravljanja (Dovey, 2012), eden izmed njegovih rezultatov je tudi prostorska ureditev. Omenjena občutljivost spodbuja prožnost in sposobnost preživetja sive ekonomije v moderniziranem mestu pod stalno grožnjo deložacije. Opisane raziskave poudarjajo dejstvo, da je prostor družbena prvina, saj nastaja v vzajemnih odnosih, ki oblikujejo družbene odnose in ti hkrati oblikujejo njih (Lefebvre, 1991; Shields, 1998). Produkcija mestnega prostora se torej ne nanaša samo na preprosto načrtovanje posameznih vrst rabe materialnega prostora, ampak bolj na produkcijo in reprodukcijo vseh vidikov mestnega življenja (McCann, 2002). Po Lefebvru je to, kako ulični prodajalci uredijo svoj prostor, prikrit družbeni red, ki se uporablja za ureditev skupnega območja (Ostrom, 2005). Ulični prodajalci skupaj s kupci in drugimi deležniki, ki imajo korist od njihove prisotnosti, ustvarjajo primerne prodajne prostore.

Avtorji v članku predstavljajo lokacijske preference, ki usmerjajo ulično prodajo, in kako prodajalci ustvarjajo prostorske ureditve na podlagi samoorganizacije. Konkretno razkrijejo družbeni sistem, na katerem temelji produkcija uličnega prodajnega prostora na nedeljski tržnici v Kuteku v Indoneziji, s čimer želijo obogatiti arhitekturni diskurz o mestni sivi ekonomiji.

\section{Metoda}

Avtorji so v raziskavi proučevali območje Kukusan Teknik v občini Depok v Zahodni Javi, kot je prikazano na Sliki 1. Izbrali so ga zaradi ulične prodaje, ki ob nedeljah dopoldne poteka v stanovanjski soseski na tem območju. Ulični prodajalci z vseh treh največjih tradicionalnih tržnic v Depoku pridejo v Kukusan prodajat blago vsako nedeljo od 6. do 10. ure. Od 80 do 200 uličnih prodajalcev redno prodaja svoje izdelke vzdolž 300 metrov dolge ulice, ki se spremeni v začasno tržnico na robu stanovanjske soseske.

V raziskavi je bil uporabljen kvalitativni pristop v treh fazah. V prvi fazi, ki je potekala februarja in marca 2015, so avtorji pregledali literaturo in na njeni podlagi zbrali najnovejše iz- 
sledke na obravnavanem področju. Sredi marca 2015 je sledil predhodni terenski ogled, na podlagi česar je bila v skladu $s$ teoretičnim okvirom oblikovana zgradba študije primera. Med terenskim ogledom je bilo določenih več pomembnih lokalnih akterjev, kot so vodja združenja stanovalcev soseske (v nadaljevanju: vodja ZSS), vodja združenja lokalnih uličnih prodajalcev ( $v$ nadaljevanju: vodja ZUP) in dolgoletni prebivalci soseske. Avtorji so se navedenim posameznikom predstavili in od njih pridobili soglasja za sodelovanje v raziskavi.

Druga faza raziskave, ki je potekala od aprila do junija 2015, je v glavnem vključevala terenska opazovanja in intervjuje. Prednost intervjujev pred drugimi metodami, kot so vprašalniki, je ta, da lahko vprašani s svojimi besedami opišejo svoje izkušnje in pojasnijo, kako živijo (Valentine, 2005: 111). Med terenskimi opazovanji so bili dokumentirani spreminjajoče se število uličnih prodajalcev, izdelki, ki jih prodajajo, in njihova prostorska ureditev. Na podlagi prodajnih izdelkov so bili prodajalci razdeljeni v tri skupine: prodajalci hrane, prodajalci drugih izdelkov in ponudniki storitev (Suharto, 2004).

Intervjuji so bili izvedeni $\mathrm{v}$ dveh nizih. Najprej so bili maja 2015 intervjuvani vodja ZSS, vodja ZUP in posamezni stanovalci soseske, ki so predstavili zgodovino ulične prodaje na tem območju in proces samoorganizacije, ki ga izvajajo vsi vpleteni. Drugi niz intervjujev je bil opravljen z naključnim vzorcem uličnih prodajalcev, stanovalcev ulice, ki se začasno spremeni v tržnico, in kupcev. Prodajalci in stanovalci so pojasnili, zakaj prodajajo na navedeni lokaciji ter kako prodajalci $\mathrm{v}$ sodelovanju s stanovalci oblikujejo in izvajajo proces samoorganizacije. Kupci so pojasnili, zakaj tam kupujejo in kaj menijo o prostorskih posledicah prisotnosti uličnih prodajalcev v njihovi soseski. Število intervjuvancev v posamezni skupini je bilo različno. $V$ intervjuje je privolilo samo 50 uličnih prodajalcev. Poleg njih je bilo v 12 tednih terenskih opazovanj in intervjujev intervjuvanih še 50 družin, ki živijo v proučevani ulici (kar je precej veliko glede na to, da je v ulici 57 hiš, od katerih jih ima sedem tudi najemna stanovanja), in 300 kupcev. Intervjuvanci so bili različno stari, imeli so različne poklice in mesečne dohodke ter so živeli v različnih vrstah stanovanj.

Tretja faza raziskave, ki je potekala od julija do septembra 2015, je vključevala analizo podatkov, razpravo in zapis izsledkov. Pričevanja intervjuvancev so bila preverjena s triangulacijo (Valentine, 2005). O izsledkih so avtorji razpravljali z akademskimi kolegi na sestankih, na podlagi česar so dopolnili in dodelali rezultate raziskave. Da bi še bolj razjasnili nekatera vprašanja, so avgusta 2015 opravili še nekaj dodatnih terenskih opazovanj in intervjujev.

\section{Rezultati}

\subsection{Zgodovina in sedanje stanje nedeljske tržnice v Kuteku}

Od leta 2001 so prostori Univerze v Indoneziji vsako nedeljo odprti za javne rekreativne dejavnosti. Udeleženci večinoma prihajajo iz najbližje občine Depok in iz bližnje metropole Džakarte. Množice ljudi, ki prihajajo na to območje, so tja privabile tudi ulične prodajalce, ki so obiskovalcem ponujali najrazličnejše izdelke, od hrane in pijače do elektronskih naprav in raznih storitev. Po navedbah vodij ZSS in ZUP so lahko ulični prodajalci v okviru univerzitetnega kompleksa prodajali, če so za to plačali zadevni prispevek, pri čemer ni bilo treba, da so bili tudi uradno prijavljeni. Njihova prisotnost torej tehnično ni bila nezakonita, hkrati pa je prinašala korist vsem vpletenim: univerzi, prodajalcem in kupcem.

Opisano dobičkonosno sodelovanje se je končalo leta 2003 zaradi smrtne nesreče, ki so jo povzročili ulični prodajalci. Od takrat univerza ne dovoli več nikakršne ulične prodaje ob nedeljah. Kljub številnim protestom, na katerih so se ulični prodajalci zavzemali za to, da bi bila spet dovoljena prodaja $\mathrm{v}$ univerzitetnem kompleksu, je univerza vse njihove prošnje ostro zavrnila. Kot alternativno možnost je vodjema ZSS in ZUP ponudila preselitev uličnih prodajalcev v sosesko v neposredni bližini kompleksa, vzdolž zidu, ki obdaja univerzo. Čeprav je ulica ožja kot območje, kjer so prej prodajali, so se vsi vpleteni strinjali, da bo to nova prodajna lokacija. Izbrana je bila zaradi dveh glavnih razlogov: po eni strani je še vedno blizu univerze, zato bi jo obiskalo veliko ljudi, po drugi strani pa je to slepa ulica, na kateri prodajalci ne bi motili gibanja stanovalcev v soseski. Vodja ZSS je bil imenovan za območnega vodjo, ki naj bi upravljal prodajo in podporne dejavnosti.

Sprva so prebivalci ulice nasprotovali prisotnosti prodajalcev pred svojimi hišami. Posledice preselitve tržnice v to ulico so bile motena zasebnost, hrup, nakopičeni odpadki in ovirano gibanje prebivalcev. Po intenzivnih posvetovanjih so prebivalci privolili $\mathrm{v}$ prisotnost ulične prodaje $\mathrm{v}$ soseski, če bodo izpolnjeni naslednji pogoji: 1. prodaja lahko poteka samo ob nedeljah od 6. do 11. ure, 2. prodajalci plačujejo prispevke ZSS, ki sredstva porabi za financiranje izboljšav v soseski, 3. prodajajo lahko tudi prebivalci, 4. prodajalci morajo plačati za uporabo elektrike iz hiš na ulici, 5. vsakršno neprimerno ravnanje bo razlog za prekinitev ulične prodaje v soseski. Zaradi varnostnih razlogov se morajo vsi prodajalci prijaviti pri vodji ZSS, za zagotavljanje reda pa mora imeti vsak prodajalec stalno prodajno mesto. Leta 2003 je bilo na območju prijavljenih 105 prodajalcev, njihovo število pa se je vsako leto povečevalo. Leta 2015 jih je bilo tako že 198 (Slika 2). 

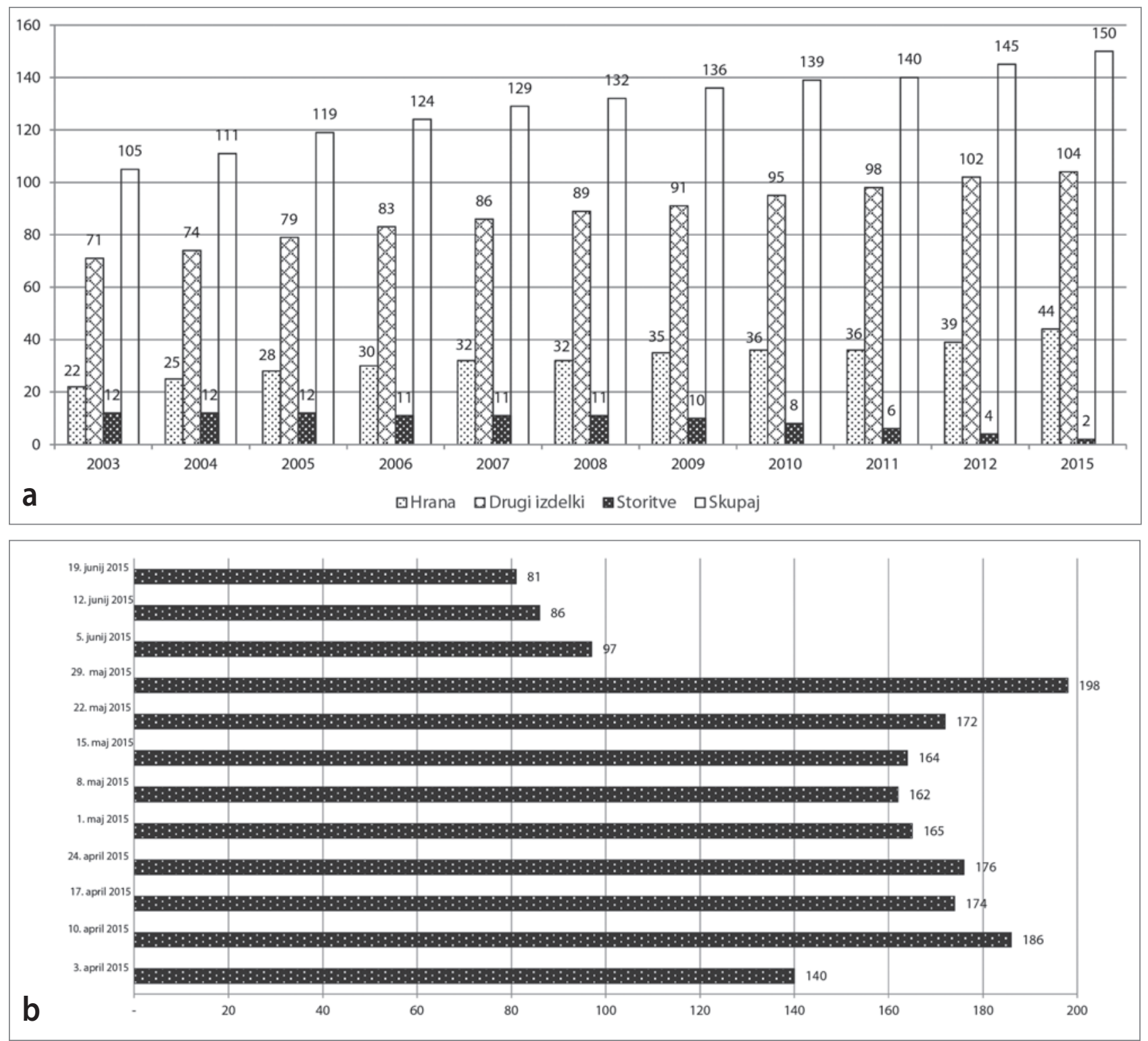

Slika 2: Skupno število uličnih prodajalcev med letoma 2003 in 2015 glede na vrsto prodajnih izdelkov (a) ter skupno število uličnih prodajalcev vsako nedeljo od 3. aprila do 19. junija 2015 (b) (ilustracija: Mitchell Edbert Suryanto)

Med 12-tedenskim opazovanjem je število uličnih prodajalcev nihalo med 81 in 198. Pouk na univerzi je potekal od februarja do junija 2015, pri čemer se je število uličnih prodajalcev s 140 na začetku aprila povečalo na 198 ob koncu maja. Ob koncu izpitnega obdobja na začetku junija je večina študentov zapustila študentsko naselje in odšla domov, zaradi česar se je število ljudi na območju močno zmanjšalo. Posledično je tudi število uličnih prodajalcev strmo padlo: zadnje tri tedne proučevanega obdobja jih je bilo manj kot 100, zadnji teden pa celo 81 . Navedeno nihanje razkriva neposreden vpliv prisotnosti študentov na število uličnih prodajalcev na nedeljski tržnici v Kuteku.

\subsection{Vzajemne koristi za vse vpletene akterje}

Prodajalci so navedli, da v glavnem prodajajo na treh tradicionalnih tržnicah v občini Depok: na tržnici PAL (34,15 \%), tržnici Kemiri $(36,59 \%)$ in tržnici Jaya Depok $(29,27 \%)$. Večina jih na nedeljski tržnici v Kuteku prodaja zato, da se izognejo hudi konkurenci na tradicionalnih tržnicah ob koncu tedna. Čeprav tradicionalne tržnice ob koncu tedna pritegnejo ogromno obiskovalcev, se zaradi precej večjega števila konkurenčnih prodajalcev njihov prihodek pomembneje ne poveča. Zato ob nedeljah raje pridejo na tržnico v Kuteku, kjer je manj prodajalcev. Drug ključni razlog so nizki upravni stroški. Štirinajst prodajalcev je v intervjujih razkrilo, da so upravni stroški na večjih tradicionalnih tržnicah tri- do petkrat višji kot na 
nedeljski tržnici v Kuteku. Tudi zaradi tega je nedeljska prodaja v Kuteku tako privlačna.

Čeprav tudi lokalni prebivalci prodajajo na nedeljski tržnici, niso vsi navdušeni nad njeno prisotnostjo na njihovi ulici. Družinski člani v devetih hišah (18 \%) so navedli, da jih tržnica moti, čeprav omogoča številne prednosti. Motijo jih predvsem smeti. Čeprav po zaprtju tržnice vse smeti pobere za to zadolžen uslužbenec, številne intervjuvance moti, da jih morajo gledati in vonjati. Druga pomembna nevšečnost je ovirano gibanje, saj se prebivalci težko prebijejo skozi množico obiskovalcev. Družine so kot tretjo težavo navedle hrup, več pa jih je omenilo tudi, da množice obiskovalcev v neposredni bližini stanovanjskih hiš motijo zasebnost stanovalcev. Kljub vsem navedenim težavam večina stanovalcev, ki je izrazila nezadovoljstvo, sprejema nedeljsko tržnico na svoji ulici. Prodaja omogoča finančno korist celotni skupnosti in mnogim posameznikom. Prebivalci prodajalcem zagotavljajo najrazličnejše podporne storitve, kot so dostop do elektrike, stojnice in skladiščne prostore, kar jim prinaša dodaten zaslužek. Sredstva, ki jih vsak prodajalec plača za najem prodajnega prostora in odvoz smeti, se porabijo za plačo upravnika tržnice in izboljšave $\mathrm{v}$ soseski.

Tržnica skupnosti omogoča številne koristi. Dvajset stanovalcev ( $40 \%)$ je navedlo, da tako lahko v neposredni bližini dobijo najnujnejše stvari, dvanajst intervjuvancev (24\%) pa je povedalo, da jih prisotnost množice obiskovalcev in različnih prodajnih izdelkov zabava. Devet intervjuvancev $(18 \%)$ je navedlo, da tržnica prebivalcem prinaša zaposlitvene priložnosti in dodaten prihodek. Nekateri tudi sami prodajajo na tržnici, mnogi pa izboljšajo svoje prihodke z zagotavljanjem podpornih storitev prodajalcem.

Vsak prodajalec mora prispevati v sklad, namenjen izboljšavam v soseski. Po navedbah vodij ZSS in ZUP ter lokalnih voditeljev skupnost zbrana sredstva porabi za prenovo ulice, popravilo odtočnega kanala vzdolž ulice in vzdrževanje mejnega zidu z univerzo. Pred odprtjem tržnice leta 2003 stanovalci niso imeli skupnega računa, namenjenega izboljšavam v soseski. Od njenega odprtja pa se je zaradi učinkovitega upravljanja sredstev, ki jih prispevajo ulični prodajalci, podoba soseske izboljšala brez kakršne koli vladne pomoči. Čeprav tržnica povzroča več okoljskih težav (npr. smeti, ovirano gibanje, hrup in pomanjkanje zasebnosti), hkrati zagotavlja pomembne družbene in gospodarske koristi. Ne glede na to, da je na zaprtem območju (tj. v ozki slepi ulici, v kateri običajno ni prav veliko ljudi), pritegne kupce iz celotne občine Depok in celo iz Džakarte. Večina intervjuvancev $(44,33 \%)$ je navedla, da tržnico redno obišče vsako nedeljo.
Večina kupcev $(44,67 \%)$ živi v občini Depok zunaj območja Kukusan. Iz Kukusana prihaja skoraj enak delež kupcev (41,67 \%), 13,67 \% pa jih živi v Džakarti. Skoraj polovica obiskovalcev $(49,67 \%)$ na tržnico prihaja po najnujnejše stvari in že vnaprej ve, kaj želi tam kupiti. Drugi tja prihajajo zaradi vzdušja $(28,67 \%)$ ali na nedeljski izlet s prijatelji $(21,67 \%)$. Ti kupci na tržnici uživajo kljub gneči in nekoliko umazanemu okolju. Nedeljska tržnica v Kuteku torej omogoča korist vsem vpletenim: prodajalcem, kupcem in lokalnim prebivalcem. Opisane skupne koristi so mogoče, ker udeleženci upoštevajo družbeno izpogajana in sprejeta pravila, ki urejajo pravice in dolžnosti vseh sodelujočih akterjev, kar omogoča usklajeno prodajno dejavnost.

\subsection{Prostorska samoorganizacija: od urejene do razdrobljene prostorske členitve}

Pri izvajanju sistema prijave uličnih prodajalcev med letoma 2003 in 2012 sta se vodji ZSS in ZUP dogovorila o prostorski ureditvi nedeljske tržnice v Kuteku, ki temelji na umeščanju prodajnih prostorov glede na vrsto izdelkov, ki se prodajajo, ter na določanju parkirnih, skladiščnih in nakladalnih območij. Ureditev je rezultat dogovora med obema vodjema, vsemi uličnimi prodajalci in prebivalci ulice ter omogoča korist vsem, ne da bi kakor koli ogrožala varnost soseske (Slika 3).

Ker se je število prodajalcev nenehno večalo, hkrati pa so na tržnici začeli sodelovati tudi mnogi občasni prodajalci, sta vodji ZSS in ZUP le stežka prijavljala vse nove člane in jim dodeljevala prostor na tržnici. Občasni prodajalci so na nedeljsko tržnico v Kuteku začeli prihajati leta 2010. Gre za potujoče prodajalce, ki se čez dan z vozovi ali kolesi selijo od ene tržnice do druge. Na tržnici v Kuteku ne prodajajo vsako nedeljo, zato nimajo stalnega prodajnega prostora. Kljub temu jim je vodja ZSS dovolil, da prodajajo na tržnici, saj so privolili v plačilo zahtevanega prispevka. Ker se je število prodajalcev nenehno spreminjalo, je leta 2012 vodja ZSS zaustavil prijavo novih prodajalcev. Z občasno prodajo so se začeli ukvarjati tudi mnogi posamezniki, ki živijo na tej ulici, pri čemer kot prodajni prostor uporabljajo svoje sprednje terase, hiše pa so preuredili v proizvodne prostore. Leta 2010 se je s prodajo ukvarjalo šest stanovalcev, do leta 2015 pa se je njihovo število potrojilo. Sprva so prodajali le občasno, zdaj pa na tržnici sodelujejo stalno. Kot je razvidno s Slike 4, prisotnost potujočih prodajalcev in lokalnih prebivalcev med prodajalci na nedeljski tržnici v Kuteku otežuje njeno prostorsko urejanje. Zaradi njihovega spreminjajočega se števila in prostorske fleksibilnosti sta jih vodji ZSS in ZUP prisiljena umestiti na kateri koli prostor, ki je še na razpolago (npr. med stojnice stalnih prodajalcev). Niz tovrstnih in nenehno spreminjajočih se »vdorov « na tržnico krni njeno nadzorovano prostorsko ureditev. 


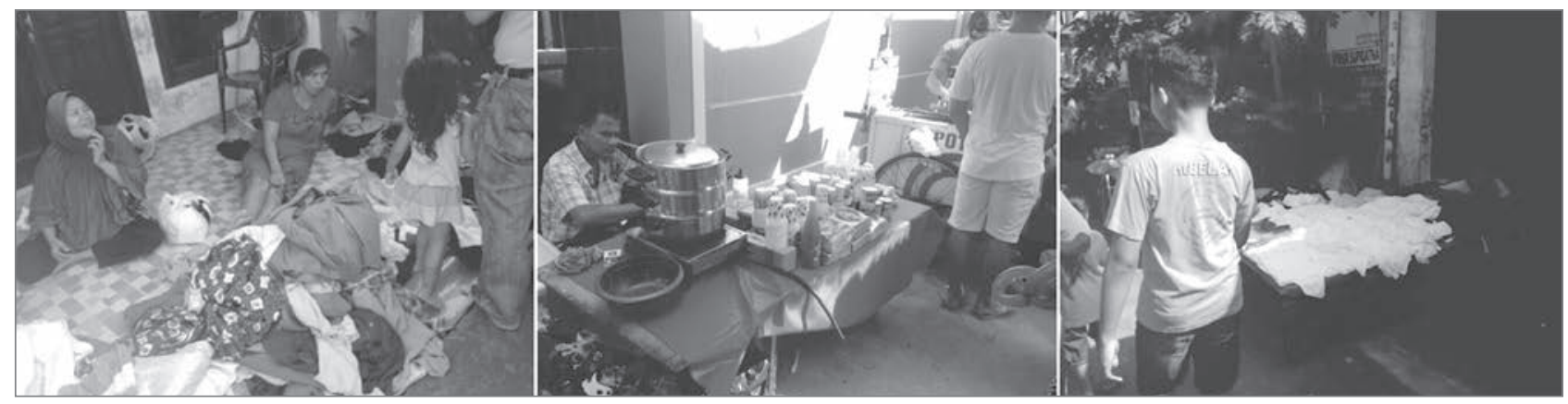

Slika 3: Stanovalci prodajajo blago pred svojimi hišami (foto: Mitchell Edbert Suryanto)

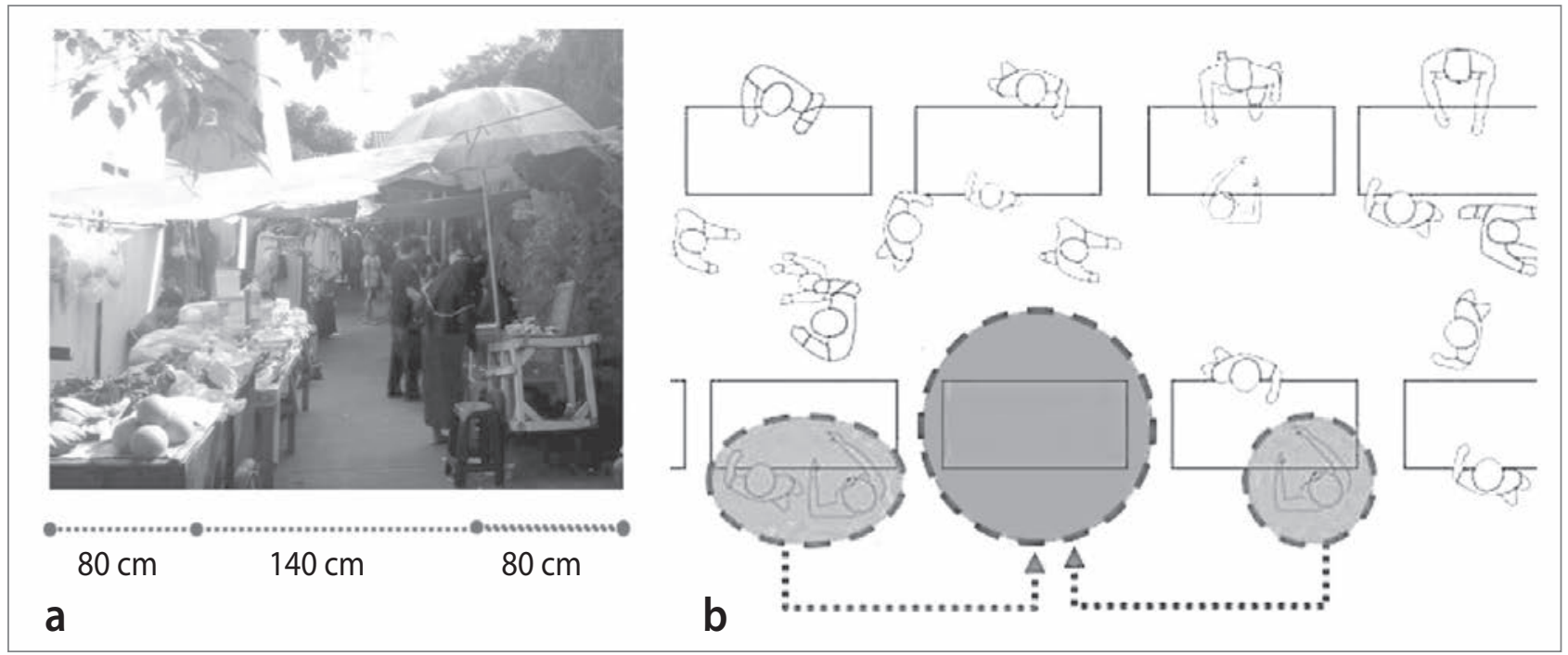

Slika 4: Velikost stojnic in širina prehoda (a) ter prikaz, kako sosednji prodajalci nadzirajo vmesno prazno stojnico (b) (foto in ilustracija: Mitchell Edbert Suryanto)

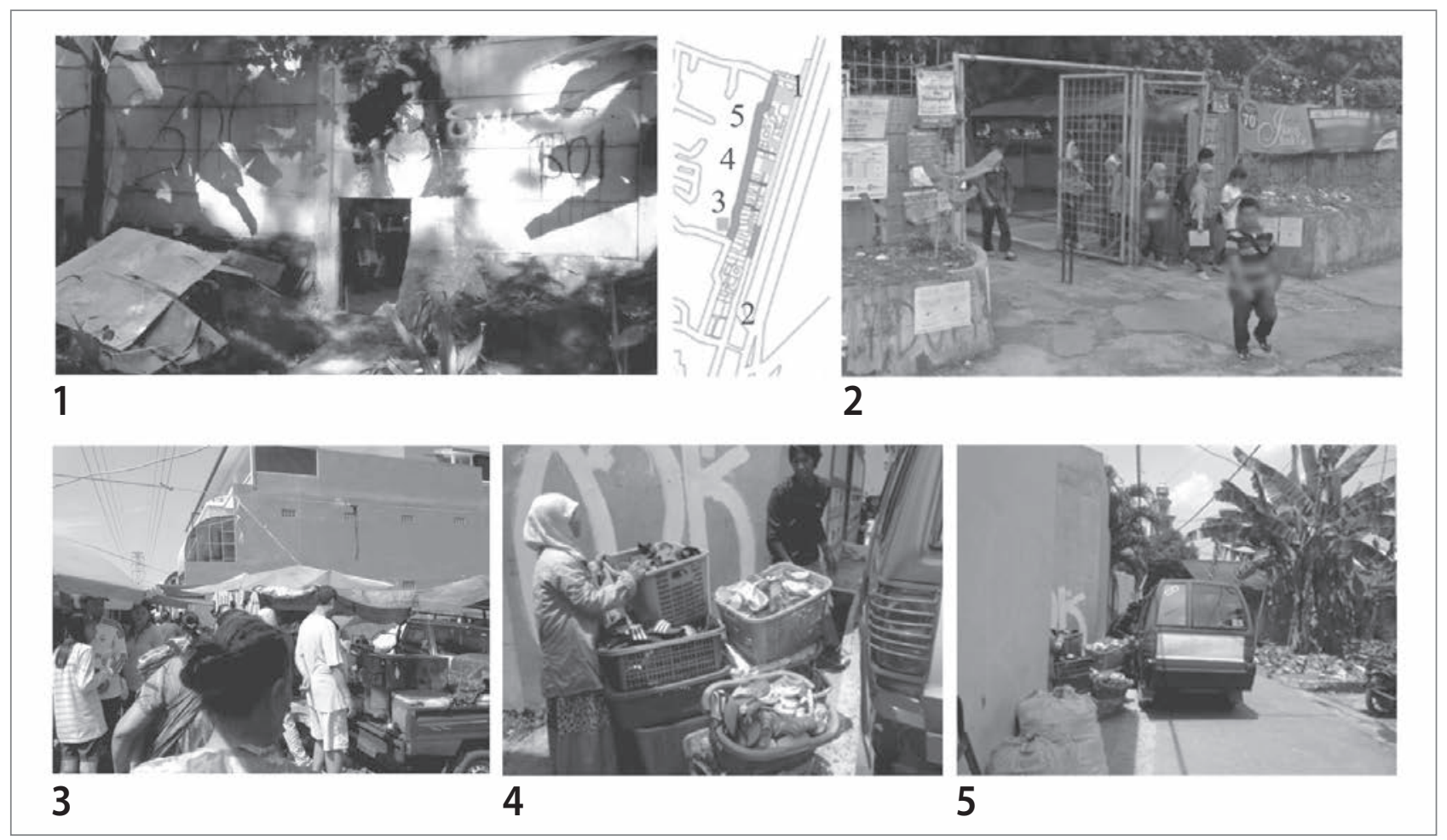

Slika 5: Ureditev gibanja pešcev (1 in 2) in prodajalcev (3, 4 in 5) (foto in ilustracija: Mitchell Edbert Suryanto) 


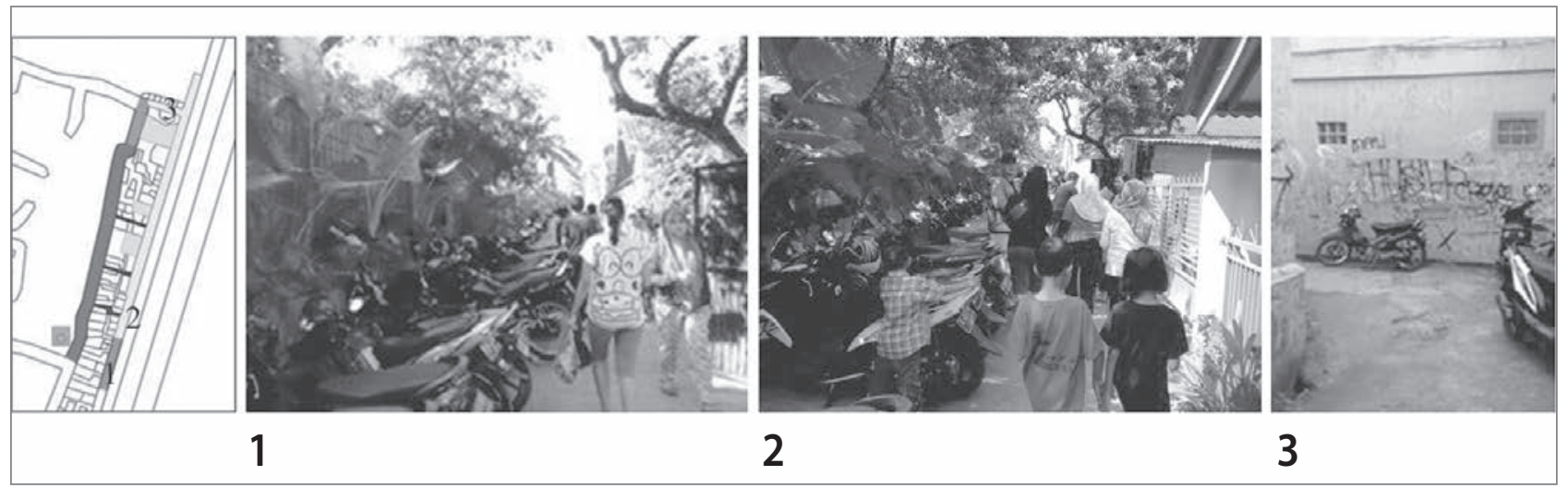

Slika 6: Parkirišča na južnem (1 in 2) in severnem (3) delu tržnice (foto in ilustracija: Mitchell Edbert Suryanto)

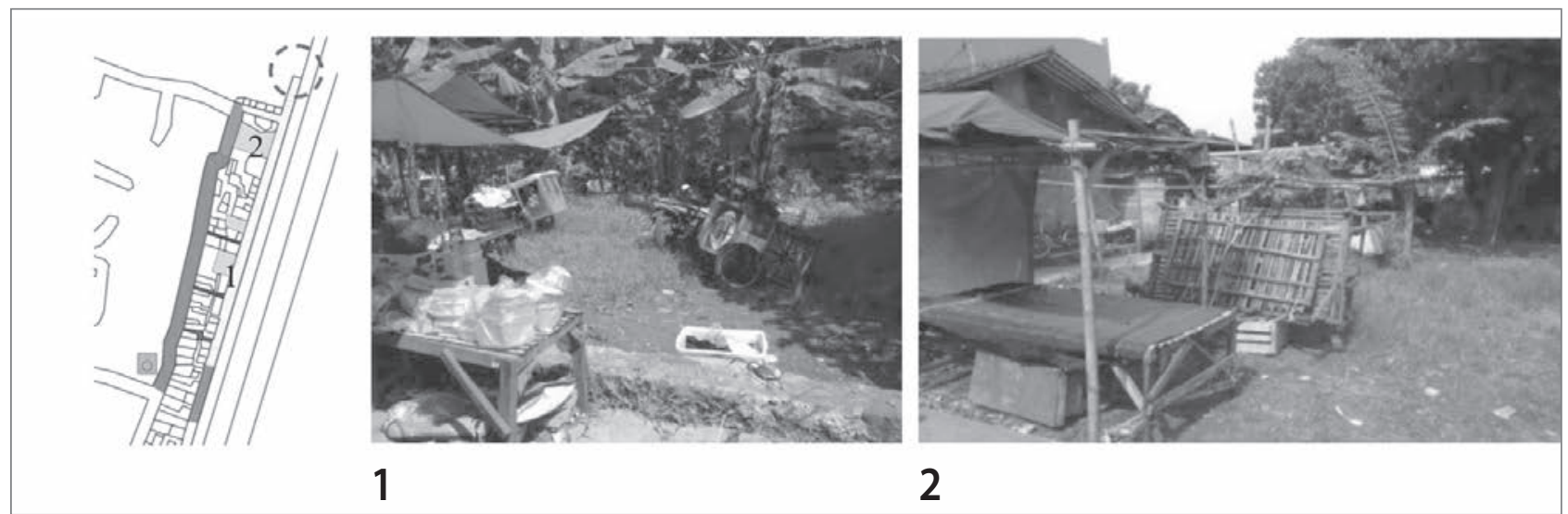

Slika 7: Prostori za shranjevanje lesenih stojnic vzdolž ulice (foto in ilustracija: Mitchell Edbert Suryanto)

Stalni prodajalci in stanovalci nimajo nič proti dodatnim prodajalcem, čeprav imajo zaradi njihove prisotnosti vsi manj prostora za prodajo. Stalni prodajalci prisotnost drugih dopuščajo v znak spoštovanja lastnega poklica. Zavedajo se, da je njihovo preživetje odvisno od vzajemne podpore in sodelovanja. Poleg tega upajo, da bo prisotnost občasnih prodajalcev vsem povečala dobiček, saj lahko njihovi izdelki pritegnejo dodatne kupce, navedeno tudi spodbuja njihovo sodelovanje. Namesto da bi ovirali občasne prodajalce, stalni prodajalci postanejo odločevalci, ki določajo možne lokacije novih občasnih prodajalcev. Kljub negativnemu vplivu na vizualno urejenost tržnice prodajalci ne nasprotujejo prisotnosti dodatnih občasnih prodajalcev na nedeljski tržnici v Kuteku, dokler ti zagotavljajo dodatne izdelke, ki pritegnejo še več kupcev, in niso neposredna konkurenca že uveljavljenim prodajalcem. Tržnica ima vhod na severu in jugu, kar obiskovalcem omogoča, da vanjo vstopajo iz dveh smeri (Slika 5). Varnost je na območju univerze skrb vzbujajoča, saj so bila tam v preteklosti že zagrešena razna kazniva dejanja. Severni vhod je pravzaprav odprtina v zidu, ki obdaja univerzitetni kompleks in so jo ustvarili lokalni prebivalci, da bi lahko dostopali do univerze, če so bila južna vrata zaprta. Posledično se vsi obiskovalci premikajo z južnega dela tržnice proti severu in se nato vračajo proti jugu, ko jo želijo zapustiti. Navedeno med 8 . in 11. uro povzroča velike zastoje in gnečo na tržnici.
Da bi zmanjšali gnečo in omogočili lažje gibanje, so se vodji ZSS in ZUP ter stanovalci dogovorili, da se zahodna ulica ob tržnici uporablja kot dovozna pot za nakladanje in razkladanje izdelkov. Območje prodajalci poleg tega uporabljajo tudi kot parkirišče za svoja vozila. Mnogi obiskovalci pridejo na tržnico z motociklom. Po navedbah vodje ZSS vsako nedeljo tržnico obišče okoli 100 ljudi na motociklih, kar zahteva veliko parkirnih mest, ki se morajo ustrezno varnostno nadzorovati, hkrati pa ne smejo otežiti gibanja pešcev na tržnici (Slika 6).

Prodaja zahteva uporabo stojnice, na kateri lahko prodajalci razstavijo svoje blago. Velikost stojnice je odvisna od števila izdelkov, ki jih prodajalec prodaja, pri čemer je večje stojnice težje premikati. Upravljavci tržnice (tj. vodji ZSS in ZUP ter stanovalci) oddajajo v najem stojnice, ki jih iz rabljenega lesa in bambusa izdelujejo mladi brezposelni prebivalci ulice. Sprva so nameravali najemne stojnice shranjevati na severnem koncu ulice, kjer ni pešcev in motociklistov, ker pa je število stojnic naraslo, so manjše zelene površine spremenili v dodaten prostor za shranjevanje, tako da stojnice ne ovirajo gibanja med tednom ali na tržnici ob nedeljah (Slika 7).

Zemljišče, na katerem stojijo najemne stojnice, je v lasti lokalne skupnosti. Upravniki tržnice, ki so tudi lastniki stojnic, so s sta- 
novalci dosegli dogovor o uporabi območja, ki je v korist vsem. Prodajalci imajo prostor, kjer lahko prodajajo svoje izdelke in ustvarjajo prihodek, ob tem tudi stanovalci ustvarjajo dodaten prihodek, saj jim prodajalci plačajo za uporabo elektrike. Tudi soseska, ki jo predstavlja vodja ZSS, nekaj zasluži in s pridobljenimi sredstvi financira svoje izboljšave. Poleg tega tržnica omogoča zaposlitvene priložnosti brezposelnim stanovalcem, ki lahko s tem lažje preživljajo svoje družine, kupcem pa v neposredni bližini njihovih domov zagotavlja različne dobrine in storitve, ki jih potrebujejo. Zaradi vzajemnih koristi, ki jih zagotavlja dosežen dogovor, se lahko javni prostor in nekateri deli zasebnih zemljišč uporabljajo za namene tržnice.

Čeprav se prodajalci običajno strogo držijo pravil, ki veljajo na tržnici, so vseeno nastali konflikti. Kot je priznal vodja ZUP, prodajalci niso ustrezno poskrbeli za ogromne količine odpadkov, ki so jih ustvarili. Za to niso imeli dovolj časa in ljudi, hkrati pa na območju tudi ni bilo dovolj zabojnikov za odpadke. Stanovalci so se na koncu pritožili vodji ZUP in zahtevali takojšno rešitev problema. Vodji ZUP in ZSS ter stanovalci so se o zadevi pogovorili in se odločili, da bodo najeli smetarje, ki jih bodo plačali tako, da bodo od prodajalcev pobirali dodaten prispevek. Storitev opravljajo lokalni prebivalci, ki se $s$ tem rešijo brezposelnosti. Po potrebi vsak prodajalec uporablja elektriko iz najbližje hiše. Ko postavljajo svoje stojnice, do hiš speljejo električne kable in elektriko plačajo neposredno stanovalcem.

\section{Razprava}

Vzajemne koristi vseh vpletenih so glavni dejavnik pri produkciji prodajnega prostora v soseski. Prostor se producira in razvija z družbenimi odnosi, kot pravi Lefebvre (1991), ter z upoštevanjem gospodarskih dejavnikov in dejavnikov, ki vplivajo na kakovost življenja prodajalcev, prebivalcev in nakupovalcev. Da bi dosegli pričakovane koristi, so vsi vpleteni ustvarili sistem prostorske samoorganizacije in uporabili razpoložljivi javni prostor za prodajo. V zameno za ugodno plačilo lokalni prebivalci prodajalcem zagotavljajo prodajni prostor in parkirna območja, urejajo gibanje pešcev, blaga in vozil, skrbijo za odstranjevanje in odvoz odpadkov ter oddajajo v najem stojnice. Nizka cena posameznih storitev prodajalcem omogoča, da prodajajo izdelke dovolj ugodno, da si jih njihove stranke lahko privoščijo. Vzajemne koristi poleg tega odtehtajo negativne vplive tržnice na skupnost, kot so številne smeti, ovirano gibanje, hrup in motena zasebnost. Družbeni odnosi, ki se ustvarjajo v dogovorih, katerih cilj je doseči vzajemno korist, se ob vprašanjih, ki zahtevajo takojšnje rešitve, še dodatno izpopolnjujejo. Zaradi naraščajočega števila potujočih in občasnih prodajalcev na tržnici je bilo treba spremeniti sistem prijave in pravila za prodajna mesta. Zaradi čedalje več prodajalcev je bilo treba zagotoviti tudi več prostora, pri čemer je moralo še več prebivalcev dovoliti prodajo pred svojimi hišami. Sprva so prodajalci na nedeljski tržnici v Kuteku izkoriščali prisotnost množic, ki so v univerzitetni kompleks prihajale zaradi rekreacije, danes pa je tržnica njihova glavna destinacija. Čeprav je od tragične nesreče leta 2003 tržnica na manj privlačni lokaciji, še vedno pritegne veliko prodajalcev in kupcev. Študija primera, predstavljena v tem članku, kaže, da število pešcev, ki prihajajo na neko območje, še ne določa lokacije uličnih prodajalcev ter da sta za uspešno delovanje ulične tržnice poglavitni dostopnost in bližina velikega števila ljudi.

Raziskava je pokazala sposobnost samoorganizacije lokalnih prebivalcev, $s$ katero rešujejo negativne vplive tržnice. Ob selitvi prvotne tržnice je bil nov prostor zagotovljen na podlagi vzpostavljenih družbenih odnosov med vpletenimi stranmi in posledičnega dogovora, ki je bil sprejemljiv za vse. Družbeni odnosi niso nevtralni, ampak temelijio na natančnih ekonomskih izračunih, ki omogočajo korist vsem vpletenim. Brez možnosti doseganja skupnih koristi ne bi bilo mogoče zagotoviti učinkovite prostorske ureditve. Zaradi potencialnih vzajemnih koristi se vsi vpleteni prizadevajo ustvariti in ohranjati prostorsko ravnovesje med trgovskimi dejavnostmi in vsakdanjim življenjem lokalnih prebivalcev v ozki ulici. Navedena ugotovitev kaže, kako neformalne dejavnosti delujejo v formalnem sistemu (Dovey, 2012). S samoregulacijo se javni prostor in nekateri deli zasebnih zemljišč spremenijo v skupen prostor (Ostrom, 2005) s posebnim in občutljivim novim družbenim redom. Poleg tega samoregulacija spodbuja doseganje skupnih koristi za vse vpletene, hkrati pa zmanjšuje negativne vplive na sosesko. Navedeno se nanaša na prožnost in sposobnost preživetja sive ekonomije v moderniziranem mestu, ki ju omenjata Obeng-Odoom (2011) in Peters (2013).

Kljub temu siva ekonomija ne bi smela biti razumljena kot posledica prožnosti in sposobnosti preživetja (ObengOdoom, 2011; Peters, 2013), ampak kot način zadovoljenja različnih interesov vpletenih akterjev. Lokacija tržnice je bila izbrana na podlagi dogovora med vodjem soseske, prebivalci in prodajalci, v skladu s katerim je bila za odmaknjeno ulico oblikovana nova tedenska dejavnost. Ustvarjeni prostorski in družbeni sistem odmaknjeno ulico povezuje s potrošniki, kar koristi prodajalcem in prebivalcem, hkrati pa je bolje poskrbljeno tudi za odvoz odpadkov. Zagotavlja zaposlitev prebivalcem in prodajalcem ter sredstva za izboljšave $\mathrm{v}$ soseski. Izmenjuje se s pristopom ničelne vsote, značilnim za formalni sektor, ter tako vzpostavlja sporazumen prostorski in družbeni sistem, ki zadovoljuje interese vseh vpletenih ter ustvarja nov sklenjen prostor, povezan $s$ prostorom formalnih dejavnosti. Siva ekonomija oziroma neformalni sektor tako ni samo alternativen, sporen prostor, ampak prostor, ki je povezan in soodvisen $s$ formalnim sektorjem. Opisano sodelovanje med obema sektor- 
jema prinaša skupne koristi, kar zmanjšuje negativne posledice neformalnega sektorja. Sčasoma ta postane sestavni del celotnega družbenega in gospodarskega sistema, pri čemer je ločnica med formalnim in neformalnim močno zabrisana.

\section{Sklep}

Prisotnost neformalnega gospodarskega sektorja, vključno z ulično prodajo, ob pomembnih koristih za preživetje mestnih prebivalcev povzroča tudi okoljske težave na mestnih območjih. Zato je treba poiskati načine za vključitev sive ekonomije $\mathrm{v}$ mestno okolje, kar bi povečalo njene koristi in zmanjšalo njene pomanjkljivosti. Ulična prodaja je ključna za preživetje trgovcev ter lokalnih prebivalcev in okoliških nakupovalcev, zato njena popolna prepoved zagotovo ni zaželena. $\mathrm{V}$ proučevanem primeru so po prisilni preselitvi tržnice s prejšnjega območja ulični prodajalci za novo prodajno lokacijo, ki je še vedno dostopna njihovim kupcem, izbrali območje Kuteka. Tržnica zaseda prostor na ulici v stanovanjskem predelu $\mathrm{Ku}-$ teka, kar je zahtevalo obsežno sodelovanje in pogajanja, na podlagi česar so bile dosežene vzajemne koristi za prodajalce in lokalne prebivalce. Prodajalci si lahko tako še vedno služijo kruh, prebivalci pa so dobili nove možnosti zaposlitve in ustvarjanja dodatnega prihodka. Za doseganje želenih ciljev prodajalci in prebivalci uporabljajo sistem samoorganizacije, $s$ katerim upravljajo prodajo in njene podporne dejavnosti. Sistem ureja prostor, gibanje, komunalne storitve in druge zadeve ter se razvija v skladu z lokalnimi razmerami, pri čemer skrbi za to, da se ohranjajo koristi vsake skupine deležnikov. Študija primera kaže, da lahko skupnosti oblikujejo učinkovit sistem samoorganizacije, ki zadovoljuje njihove trenutne potrebe.

Samoorganizirani sistemi imajo običajno omejeno zmogljivost in pogosto zahtevajo sodelovanje z zunanjimi akterji. Navedeno sodelovanje je pomembno, saj sta formalni in neformalni sektor odvisna drug od drugega in tvorita skupen gospodarski sistem, v katerem so ločnice med njima močno zabrisane. Primerni posegi na področju družbenega razvoja ter urbanističnega načrtovanja in oblikovanja lahko sivi ekonomiji na mestnih območjih pomagajo, da postane donosna in ima pozitivne posledice. Tovrstni posegi morajo zadovoljiti interese vseh vpletenih strani, saj se $s$ tem izognemo nasprotovanjem ali novim oviram v prihodnosti. Za potrditev koristi, ki jih neformalni sektorji prinašajo mestnim skupnostim, in proučitev različnih načinov zmanjšanja njihovih morebitnih pomanjkljivosti so potrebne nadaljnje multidisciplinarne raziskave, $s$ katerimi bi proučili, kako lahko povežemo formalne in neformalne gospodarske sektorje na mestnih območjih.

Mitchell Edbert Suryanto

Department of Architecture, Faculty of Engineering, Universitas Indonesia (Oddelek za arhitekturo, Fakulteta za gradbeništvo, Univerza v Indoneziji), Depok, Indonezija

E-naslov: mitchell.edbert93@gmail.com

Joko Adianto

Department of Architecture, Faculty of Engineering, Universitas Indonesia (Oddelek za arhitekturo, Fakulteta za gradbeništvo, Univerza $v$ Indoneziji), Depok, Indonezija

E-naslov: joko.adianto@ui.ac.id

Rossa Turpuk Gabe

Department of Architecture, Faculty of Engineering, Universitas Indonesia (Oddelek za arhitekturo, Fakulteta za gradbeništvo, Univerza v Indoneziji), Depok, Indonezija

E-naslov: rossa@ui.ac.id

\section{Zahvala}

Avtorji se Direktoratu za raziskave in vključenost skupnosti Univerze v Indoneziji (DRPM UI) zahvaljujejo za finančno podporo v okviru programa Hibah Publikasi Artikel di Jurnal International Kuartil Q1 dan Q2 (Q1Q2) Tahun Anggaran 2019 (št. projekta NKB- 0305/UN2. R3.1/HKP.05.00/2019) in Oddelku za arhitekturo na tehniški fakulteti Univerze v Indoneziji (FTUI) za pomoč pri raziskavi. Poleg tega se iskreno zahvaljujejo vodji združenja stanovalcev soseske 1 v Kuteku za odobritev raziskave in njegovo aktivno sodelovanje $v$ njej. Hkrati se za vztrajnost in izjemno delo $\mathrm{v}$ fazi zbiranja podatkov zahvaljujejo Soimanu, Mohammadu Hassanu, Mohammadu Ibnuju, Agusu Widodu, Adi Nugroho, Rudiju Harisu in Alexu Wibowu.

\section{Viri in literatura}

Adianto, J. (2009): Trotoar sebagai ruang pejalan kaki dan pedagang kaki lima [Sidewalks as spaces for pedestrians and street vendors]. Džakarta, Directorate of Higher Education, Ministry of Education and Culture Republic of Indonesia. Tipkopis.

Anjaria, J. S. (2006): Street hawkers and public space in Mumbai. Economic and Political Weekly, 41, str. 2140-2146.

Bhowmik, S. K. (2005): Street vendors in Asia: A review. Economic and Political Weekly, 40(22-23), str. 2256-2264.

Boeri, S. (2003): Multiplicity. Milan, Skira.

Brown, A. (2006): Contested space: Street trading, public space, and livelihoods in developing cities. Warwickshire, Intermediate Technology Publications Ltd.

Chai, X., Ziqiang, Q., Pan, K., Deng, X., in Zhou, Y. (2011): Research on the management of urban unlicensed mobile street vendors: Taking public satisfied degree as value orientation. Asian Social Science, 7(12), str. 163-167. DOI: 10.5539/ass.v7n12p163

Chen, M. A. (2007): Rethinking the informal economy: Linkages with the formal economy and the formal regulatory environment. Dostopno na: https://www.wider.unu.edu/publication/rethinking-informal-economy (sneto 8. 10. 2018). DOI: 10.1093/0199204764.003.0005

Chirisa, I. (2009): The geography of informal sector operations (ISOs): A perspective of urban Zimbabwe. Journal of Geography and Regional Planning, 2(4), str. 66-79.

Chiu, C. (2013) Informal management, interactive performance: Street vendors and police in a Taipei night market. International Development Planning Review, 35(4), str. 335-352. DOI: 10.3828/idpr.2013.24

Cohen M., Bhatt, M., in Horn, P. (2002): Women street vendors: The road to recognition. New York, Population Research Council Inc. 
Cross, J. C. (2000): Street vendors, modernity, postmodernity: Conflict and compromise in the global economy. International Journal of Sociology and Social Policy, 20(1/2), str. 29-51. DOI: $10.1108 / 01443330010789061$

Danesh, A. H. (1999) Corridor of hope: A visual view of informal economy New York, University Press of America.

Deguchi, A. (2005): Reevaluating street vendors in Asian cities and Asian Urbanism. Prispevek je bil predstavljen na konferenci z naslovom 8th International Conference of the Asian Planning Schools Association, ki je potekala od 11. do 14. septembra v Penangu v Maleziji. Tipkopis.

Deguchi, A., Takaki, K., Miura, K., in Kitamura, H. (2005): The lively space and function of 'Yatai' in Fukuoka City. Journal of Asian Urban Studies, 6(2), str. 1-10.

Dewar, D., in Watson, V. (1990): Urban markets: Developing informal retailing. London, Routledge.

Donovan, M. G. (2008): Informal cities and the contestation of public space: The case of Bogota's street vendors, 1988-2003. Urban Studies, 45(1), str. 29-51. DOI: 10.1177/0042098007085100

Dovey, K. (2012): Informal urbanism and complex adaptive assemblage. International Development Planning Review, 34(4), str. 349-367. DOI: $10.3828 /$ idpr.2012.23

Dunn, K. (2014): Street vendors in and against the Global City: VAMOS Unidos. V: Milkman, R., in Ott, E. (ur): New labor in New York: Precarious workers and the future of the labor movement. Ithaca, ILR Press. DOI: $10.7591 / 9780801470752-008$

Estrada, E., in Hondagneu-Sotelo, P. (2011): Intersectional dignities: Latino immigrants street vendor youth Los Angeles. Journal of Contemporary Ethnography, 40(1), str. 102-131. DOI: 10.1177/0891241610387926

Faruque, Q., in Haque, Q. F. (2010): Institutionalization of healthy street food system in Bangladesh: A pilot study with three wards of Dhaka City Corporation as a model. National Food Policy Capacity Strengthening Programme (NFPCSP), Final Report PR \#7/07. Daka, Consumers Association of Bangladesh.

Fidler, P., in Webster, L. (1996): The informal sector and microfinance in West Africa. Washington, DC, Svetovna banka.

Franke, A. (ur.) (2006): B-Zone: Becoming Europe and beyond. Barcelona, Actar.

Harjoko, T. Y., in Adianto, J. (2012): Topology and the web of informal economy: Case study of Kakilima and its twisted networks in the market of Kebayoran Lama, Jakarta. Asian Journal of Environment-Behaviour Studies, 3(7), str. 57-68. DOI: 10.21834/aje-bs.v3i6.248

Hossain, N. (2004): The social logic of spontaneous retail development in Dhaka. Protibesh: Journal of the Department of Architecture, 9(1).

Hossain, N. (2014): Socio-spatial dialectic of retail environment in developing countries: Perception of retail trends in Dhaka. Asian Journal of Humanities and Social Sciences, 2(4), str. 10-21.

Idayanti, S. (2007): Identifikasi pedagang kaki lima di Jalan Pancasila dan sekitarnya [Identification of street vendors in Pancala Street and its surroundings]. Tegal, Lembaga Penelitian Universitas Pancasakti Tegal.

Indira, D. (2015): A study on the organizing of street hawking business. International Journal of Management and Commerce Innovations, 2, str. 280-288.

International Labor Organization (2002): Women and men in the informal economy: A statistical picture. Geneva, ILO.

Internet 1: https://goo.gl/maps/Lpb3nTYjb8QXxHoM6 (sneto 3. 4. 2015).
Isin, E. (1999): Citizenship and identity. London, SAGE.

Iyenda, G. (2005): Street enterprises, urban livelihoods and poverty in Kinshasa. Environment and Urbanization, 17(2), str. 55-67. DOI: $10.1177 / 095624780501700205$

Jiang, S. S., Jou, S. C., in Wu, S. L. (2010): Urban redevelopment and neoliberal governance: Empirical model for (re-) developing the Taipei Main Station Special District. City and Planning, 37 (2), str. 167-191.

Jimu, I. M. (2005): Negotiated economic opportunity and power: Perspectives and perceptions of street vending in Urban Malawi. Africa Development 30(4), str. 35-51. DOI: 10.4314/ad.v30i4.22239

Kabeer, N. (2004): Re-visioning "the social": towards a citizen-centred social policy for the poor in poor countries, IDS working paper no. 191. Brighton, Institute of Development Studies.

Koolhaas, R. (2005): Lagos wide \& close: An interactive journey into an exploding city. Amsterdam, Submarine.

Koolhaas, R., in Cleijne, E. (2007): Lagos: How it works. Baden, Lars Müller Publishers.

Lefebvre, H. (1991): The production of space. Oxford, Blackwell.

Libratono, L. (2012): Preferensi and informasi spasial pedagang kakilima: Studi kasus pasar Bekasi Baru [Prefence and spatial formation of street vendors: A case study of the Bekasi Baru Market]. Magistrsko delo. Jawa Barat, University of Indonesia, Architecture Graduate Department.

Ligthelm, A. A., in van Wyk, A. M. A. (2004): Informal trading in Tshwane: Regulatory, spatial and economic framework report. Johannesburg, Bureau of Market Research South Africa.

Lincoln, M. (2008): Report from the field: Street vendors and the informal sector in Hanoi. Dialectical Anthropology 32(3), str. 261-265 DOI: 10.1007/s10624-008-9062-9.

Lindell, I. L. (2008): The multiple sites of urban governance: Insights from an African city. Urban Studies, 45(9), str. 1879-1901. DOI: 10.1177/0042098008093382

Loukaitou-Sideris, A., in Ehrenfeucht, R. (2011): Sidewalks: Conflict and negotiation over public space. Massachusetts, MIT Press.

DOI: $10.7551 /$ mitpress/7423.001.0001

McCann, E. J. (2002): Space, citizenship and the right to the city: A brief overview. GeoJournal, 58, str. 77-79.

DOI: 10.1023/b:gejo.0000010826.75561.c0

Morrell, E., Tuerah, N., in Sumarto, H. S. (2011): Local authority and pro-poor urban management in Indonesia's transition to democracy. International Development Planning Review, 33(1), str. 49-66. DOI: 10.3828/idpr.2011.4

Mörtenböck, P., in Mooshammer, H. (2007): Trading indeterminacy: Informal markets in Europe. Field Journal, 1(1), str. 73-87.

Munoz, L. (2012): Latino/a immigrant street vendors in Los Angeles: Photo-documenting sidewalks from 'back-home'. Sociological Research Online, 17(2), str. 21. DOI: 10.5153/sro.2693

Obeng-Odoom, F. (2011): The informal sector in Ghana under siege. Journal of Developing Societies, 27(3-4), str. 355-392. DOI: 10.1177/0169796x1102700406

Ong, A. (2006): Neoliberalism as exception: Mutations in citizenship and sovereignty. Durham: Duke University Press.

Ostrom, E. (2005): Understanding institutional diversity. Princeton, Princeton University Press.

Parthasarathy, D. (2003): Urban transformation, civic exclusion and elite discourse. City: A Quarterly on Urban Issues, 4, str. 9-28. 
Perera, L. A. S. R. \& Amin, A. T. M. N. (1996): Accommodating the informal sector: A strategy for urban environmental management. Journal of Environmental Management, 46(1), str. 3-15.

DOI: 10.1006/jema.1996.0002

Peters, R. (2013): Surabaya, 1945-2010: Neighbourhood, state and economy in Indonesia's city of struggle. Singapur, NUS Press.

DOI: /10.2307/j.ctv1qv2vv

Rakodi, C. (2005): The urban challenge in Africa. V: Keiner, M., Kol-Schretzenmayr, M., in Schmid, W. (ur.): Managing urban futures: Sustainability and urban growth in developing countries. Ashgate, Hampshire \& Burlington. DOI: 10.4324/9781315249827

Robins, K., in Askoy, A. (1996): Istanbul between civilization and discontent. City, 1(5-6), str. 6-33.

Rojas, M. (2008): Experienced poverty and income poverty in Mexico: a subjective well-being approach. World Development, 36(6), str. 10781093. DOI: 10.1016/j.worlddev.2007.10.005

Roy, A. (2005): Urban informality: Toward an epistemology of planning. Journal of the American Planning Association, 71, str. 147-158. DOI: 10.1080/01944360508976689

Satterthwaite, D. (2003): The links between poverty and the environment in urban areas of Africa, Asia, and Latin America. The Annals of the American Academy of Political and Social Science, 590(1), str. 73-92. DOI: $10.1177 / 0002716203257095$

Shields, R. (1998): Lefebvre, love, and struggle. London, Routledge.

Suharto, E. (2004): Accommodating the urban informal sector in the public policy process. London, Central European University Centre for Policy Studies.

Suparwoko, S. J., in Sriyana, J. (2006): Profil pedagang kaki lima (PKL): Studi kasus daerah Tumbuh Cepat di Kabupaten Sleman [Profile of street vendors: A case study of the Tumbuh Kembang area in the Sleman District]. Sleman, Direktorat Penelitian dan Pengabdian Masyarakat - UII.

Suparwoko, S. J. (2008): Renovasi jalan dan bangunan pedagang kaki lima (PKL) berbasis aspirasi stakeholders: Studi kasus Jalan Kaliurang Yogyakarta [Building renovation of street vendors based on stakeholders' aspirations: A case study of Kaliurang Street, Yogyakarta]. Prispevek je bil predstavljen na seminarju z naslovom Seminar Nasional Peran Arsitektur Perkotaan dalam Mewujudkan Kota Tropis, ki je potekal 6. avgusta $v$ Semarangu v Indoneziji. Tipkopis.

Suriansyah, Y. (2005): The existence of street vendors as a reflection of urban life: Case study of the Gasibu area in Bandung, West Java, Indonesia. Journal of Asian Urban Studies, 6, str. 43-50.

Susilo, A. (2011): Faktor-faktor yang mempengaruhi pedagang kaki lima menempati bahu Jalan di Kota Bogor: Studi kasus pedagang sembako di Jalan Dewi Sartika Utara [Factors affecting street vendors to occupy sidewalk in Bogor City: A case study of vendors of basic food in Dewi Sartika Street]. Magistrsko delo. Jakarta, Universitas Indonesia. DOI: 10.25015/penyuluhan.v2i2.2131

Valentine, G. (2005): Tell me about ...: using interviews as research methodology. V: R. Flowerdew \& D. Martin (ur.): Methods in human geography, London, Pearson Prentice Hall.

Yankson, P. W. K. (2000): Accommodating informal economic units in the urban built environment: Petty commodity enterprises in the Accra Metropolitan Area, Ghana. Third World Planning Review, 22, str. 313-334. DOI: 10.3828/twpr.22.3.p4507168258554v1

Yankson, P. W. K. (2007): Street trading and environmental management in central Accra: Decentralization and metropolitan governance in Ghana. Research Reviews, 1, str. 37-55. DOI: 10.4314/rrias.v23i1.22967
Yeo, S. J., Hee, L., in Heng, C. K. (2012): Urban informality and everyday (night)life: a field study in Singapore. International Development Planning Review, 34(4), str. 369-390. DOI: 10.3828/idpr.2012.22 